\title{
O treaty-making power na Constituição brasileira de 1988: uma análise comparativa do poder de celebrar tratados à luz da dinâmica das relações internacionais
}

\section{VALERIO DE OLIVEIRAMAZZUOLI*}

\section{Introdução}

Este ensaio se propôs a estudar a competência dos poderes constituídos para a celebração de tratados, bem como a sistemática de incorporação desses mesmos instrumentos no ordenamento jurídico brasileiro, à luz da dinâmica das relações internacionais. Para tanto, foi necessário enfocar o assunto através de uma análise pormenorizada do papel do Congresso Nacional e do Poder Executivo no procedimento de celebração de tratados internacionais, interpretando os dispositivos da Constituição de 1988 que tratam do tema.

O "poder de celebrar tratados" ou "treaty-making power" - para se utilizar da expressão de HENRY WHEATON -, foi estudado no Brasil, com pioneirismo, pelo Prof. Antônio Paulo Cachapuz De Medeiros, atual Consultor Jurídico do Ministério das Relações Exteriores (Itamaraty) que, em dois trabalhos excepcionais, analisou a competência dos poderes constituídos para a celebração de tratados à luz do direito internacional, do direito comparado e do direito constitucional brasileiro. ${ }^{1}$

Neste estudo, seguindo a esteira do citado professor, pretendeu-se conjugar o "poder de celebrar tratados" com o processo e a dinâmica de incorporação dos tratados internacionais em geral no ordenamento jurídico pátrio. Buscou-se, então, compreender como funciona a sistemática de incorporação de tratados internacionais no direito interno brasileiro. 


\section{A Constituição de 1988 e o poder de celebrar tratados}

O Brasil tem ratificado atos internacionais de grande complexidade, tanto bi como multilaterais. A presença crescente do Brasil no cenário internacional e a conseqüente intensificação dos contatos gerou, nos últimos anos, um aumento significativo de atos internacionais negociados e concluídos pelo Brasil, sobre as mais diversas matérias. Tais documentos que o governo assina em nome da República, devem ser, pelo direito interno, objeto de um tratamento igualmente complexo, que, no âmbito dos Poderes da União, dá-se pelo Executivo e pelo Congresso Nacional, em colaboração de um com o outro. ${ }^{2}$

Desde a Primeira República, até os dias atuais, o sistema adotado pelo Brasil no que tange à matéria, consagra a participação do Poder Legislativo no processo e conclusão de tratados, não tendo havido, de lá para cá, profundas modificações nos textos constitucionais brasileiros.

A competência para celebrar tratados foi intensamente discutida na Assembléia Constituinte de 1987 a 1988. Por um imperdoável lapso do legislador, no encerramento dos trabalhos, a Comissão de Redação não foi fiel à vontade do Plenário e provocou o surgimento de dois dispositivos aparentemente antinômicos: os artigos 49, I, e 84, VIII, da Constituição.

O texto final, aprovado por 474 votos a favor, 15 contra e 6 abstenções, e promulgado como a nova Constituição da República Federativa do Brasil, aos 5 de outubro de 1988, passou a dispor quanto à forma de ingresso dos tratados internacionais no direito brasileiro que:

“Artigo 84. Compete privativamente ao Presidente da República:

(...)

VIII - celebrar tratados, convenções e atos internacionais, sujeitos a referendo do Congresso Nacional; (...)"

“Artigo 49. É da competência exclusiva do Congresso Nacional:

I - resolver definitivamente sobre tratados, acordos ou atos internacionais que acarretem encargos ou compromissos gravosos ao patrimônio nacional; (...)"

Da simples leitura dos artigos transcritos é possível perceber que a vontade do Executivo, manifestada pelo Presidente da República, não se aperfeiçoará enquanto a decisão do Congresso Nacional sobre a viabilidade de se aderir àquelas normas não for manifestada, no que se consagra, assim, a colaboração entre o Executivo e o Legislativo na conclusão de tratados internacionais.

Essa conjugação de vontades entre o Executivo e o Legislativo, aliás, sempre se fez presente nas Constituições brasileiras. Excetue-se, apenas, o texto da Constituição do Império, de 1824, que dizia, no seu art. 142: "São atribuições do Imperador: (...) X-Fazer tratados de aliança ofensivos ou defensivos, de subsídio 
e comércio, levando-os porém ao conhecimento da Assembléia Geral, logo que o interesse e segurança do Estado o permitirem. Se os tratados concluídos em tempo de paz contiverem cessão ou troca de parte do território do Império ou de possessões a que o Império tenha direito, não poderão ser ratificados sem terem sido aprovados pela Assembléia Geral". Como se percebe, o imperador dava apenas ciência à assembléia geral, de que havia concluído um tratado, o que demonstra que não era necessária qualquer aprovação por parte deste órgão. Só excepcionalmente é que a aprovação legislativa se fazia obrigatória, como nos casos que envolvessem questões territoriais.

À exceção desta Carta, a aprovação legislativa para a ratificação de tratados internacionais sempre se fez presente.

\section{As divergências doutrinárias entre Hildebrando Accioly e Aroldo Valladão}

Algumas discussões doutrinárias surgiram, sob a égide dos textos constitucionais anteriores, a respeito da obrigatoriedade ou não de se passar pelo crivo do poder Legislativo todo e qualquer tipo de ato internacional assinado pelo governo. ${ }^{3}$

Os comentaristas dos textos constitucionais anteriores se dividiam, no que diz respeito à obrigatoriedade de todos os atos internacionais concluídos pelo Executivo serem aprovados pelo Poder Legislativo. Parte da doutrina entendia que ao Congresso Nacional caberia aprovar todo e qualquer ato internacional concluído pelo Poder Executivo. ${ }^{4}$ Outros já reconheciam como válidos alguns acordos internacionais produzidos tão-somente pelo Executivo, levando para tanto em conta a prática interna e internacional a respeito. ${ }^{5}$ Dessa última corrente era afiliado HiLdEBRANDo ACCioly, para quem existia a possibilidade de se concluir acordos internacionais sem a aprovação do Congresso Nacional. Para Accioly, a pedra de toque definidora de tal competência seria a matéria versada no tratado: "Se a matéria sobre que versa o tratado é da competência exclusiva do Poder Legislativo, está claro que o aludido ato não se pode tornar válido sem a aprovação legislativa; e, se depende de tal aprovação, deve ser submetido à ratificação". ${ }^{6}$ Segundo o referido publicista, independeriam de aceitação formal do Poder Legislativo os seguintes atos:

a) os acordos sobre assuntos que sejam de competência privativa do Poder Executivo;

b) os concluídos por agentes ou funcionários que tenham competência para tanto, sobre assuntos de interesse local ou de importância restrita;

c) os que simplesmente consignam a interpretação de cláusulas de um tratado já vigente;

d) os que decorrem, lógica e necessariamente, de algum tratado vigente e são como que o seu complemento; 
e) os de modus vivendi, na medida em que têm em vista apenas deixar as coisas no estado em que se encontram ou estabelecer simples bases para futuras negociações.

ACCIOLY fundamentava o seu posicionamento fazendo referência à prática norte-americana dos "acordos do executivo", que cobrem assuntos dos mais importantes e cuja validade não se subordina à aprovação do Senado americano. ${ }^{7}$ Na lição do Prof. CAChapuz de MedeIros, "mesmo nos Países onde a Constituição conserva a exigência da aprovação parlamentar para todos os tratados internacionais, formaram-se práticas diplomáticas, desvirtuadas da letra constitucional, pelas quais o Governo conclui vários tipos de ajustes, sem o consentimento das Câmaras legislativas. São os convênios denominados, na prática norte-americana, de executive agreements e, mais adequadamente chamados de acordos em forma simplificada". ${ }^{8}$

Combatendo esta tese por Accioly firmada, Haroldo Valladão, em Parecer proferido ao Ministro das Relações Exteriores Raul Fernandes, como Consultor do Itamaraty, lecionou no sentido de que é inaceitável que tratados que não dependem de ratificação sejam imunes à aprovação congressual, visto que isso importaria em pedir ao Direito Internacional a solução de um problema de exegese constitucional, o que não é admissível. $\mathrm{O}$ maior ou menor poder que o Governo de um Estado tem para negociar e assinar atos internacionais é assunto típico do direito interno de cada País, que escapa da alçada do Direito Internacional. Asseverava ainda que o Brasil é signatário da Convenção de Havana sobre o Direito dos Tratados, de 1928, que impõe a absoluta necessidade de ratificação para todos os tratados, sem exceção. Finalizou dizendo que a regra norte-americana seria inaplicável no Brasil posto que a nossa Constituição [referia-se ele à Carta de 1891, art. 48, n. $\left.{ }^{\circ} 16\right]$ não distinguiu, como fez o constituinte americano, entre tratados e ajustes de menos importância, dizendo apenas "ajustes, convenções e tratados", sujeitando-os todos ao crivo do Poder Legislativo, condição sine qua non para a sua validade e conseqüente eficácia jurídica no âmbito da soberania interna brasileira. A única exceção admitida por VALLADÃo seria a relativa aos pactos feitos por chefes militares dentro do limite de suas atribuições. ${ }^{9}$

Face a essas ponderações, AcCioly replicou, através do Boletim da Sociedade Brasileira de Direito Internacional, mesmo veículo informativo onde tinha sido publicada a crítica de HAROLDO VALLADÃO, argumentando principalmente que já na vigência da Carta de 1891 concluíram-se acordos internacionais sem aprovação do Congresso Nacional, consoante evidenciava o Código das Relações Exteriores, publicado em 1900. Considerou injustificado o argumento de que os constituintes brasileiros tiveram por vontade subordinar o Executivo ao Legislativo, visto que mesmo em países de regime parlamentar, é ao Chefe da Nação ou do Governo que cabe a condução da política exterior. Asseverava que não há na 
doutrina e jurisprudência internacionais princípio tendente à absoluta necessidade de serem ratificados, sem exceção, todos os tratados e demais compromissos exteriores. São exemplos de exceção ao princípio da absoluta necessidade de ratificação os acordos em forma simplificada. Segundo ele, até mesmo a Convenção de Havana, de 1928, admite o princípio contrário, pois estipula que "os tratados vigorarão desde a troca ou depósito das ratificações, salvo se, por cláusula expressa, outra data tiver sido convencionada". Finalmente, insiste ACCIOLY na tese da razoabilidade da competência privativa. Sendo a matéria de competência do Poder Executivo, não haveria porque, depois de aprovado o acordo, devesse o mesmo passar pelo crivo do Poder Legislativo, a fim de colocá-lo em vigor. Para ele o costume de muitos anos sempre foi o de não ser exigível a aprovação do Congresso Nacional para certos e determinados atos internacionais. ${ }^{10}$

Como informa Grandino Rodas, a prática do Ministério das Relações Exteriores, assim como a opinião de jurisconsultos ao mesmo ligados, como os consultores jurídicos LeVI CARNEIRO e REZENDE RochA, e os diplomatas NASCIMENTO e Silva e Pereira de AraúJo, seguiram a tendência de Accioly. ${ }^{11}$ Para o primeiro, somente os acordos de competência privativa do Poder Executivo, de importância secundária, poderiam deixar de ser submetidos ao Congresso Nacional. Os acordos executivos só poderiam interpretar aspectos de menor importância dos tratados. LEVI CARNEIRo afasta ainda os ajustes para prorrogação de tratados, por se assimilarem mais a tratados novos. Sua conclusão - lembra GRANDINO RODAS - é no sentido de restringir a prática de simples troca de notas nos casos em que é cabível, sem ulterior pronunciamento do Congresso. ${ }^{12}$ Para Nascimento e SiLva, além das hipóteses aventadas por ACIOLLY, não estariam sujeitos à ratificação também os acordos por troca de notas. Via de regra tais acordos tratam de assuntos de somenos importância, a exemplo da interpretação de um artigo obscuro constante de um tratado, ou de matéria administrativa. PereIra DE AraúJo entendia que, pelo fato de inexistir nas Constituições posteriores à de 1891, as palavras "sempre" e "ajustes", que dela constavam, isso criou condições para a superveniência de uma norma consuetudinária extra legem, no sentido de que os atos internacionais de menos importância estariam dispensados de aprovação pelo Poder Legislativo. O grande número de atos internacionais concluídos pelo Brasil sem a participação do Congresso Nacional estaria a evidenciar tal fato. Para Rezende RochA, quando o acordo se contiver nas atribuições do Poder Executivo ou às mesmas se circunscrever, reivindicar o assentimento do Legislativo para a ratificação de tratados importaria em contestar a própria separação de poderes e a necessidade do seu recíproco respeito. ${ }^{13}$

A controvérsia ainda mais se intensificou com a redação dos textos constitucionais de 1967 e 1969. A Carta de 1967 referia-se a "tratados, convenções e atos internacionais", servindo de base para que HAROLDO VALLADÃO reafirmasse sua opinião acerca da impossibilidade de aprovação de qualquer tipo de ato 
internacional sem a aprovação do Congresso Nacional. ${ }^{14}$ José Francisco ReZeK, nesse sentido, asseverava que defender a convalidação de atos internacionais destituídos de aprovação parlamentar com base na existência de um costume internacional, como fizeram Accioly e Pereira AraúJo, passa a ser um exercício contra legem e não mais extra legem. E costume internacional contra a letra da Constituição é incompreensível, pois contraria a lógica jurídica. Nem mesmo é indubitável ter existido o elemento psicológico do costume, pois o simples silêncio frente às publicações oficiais não perfaz a opinio juris, além do que vez por outra, ocorreram manifestações contrárias à prática. Critica também a opinião daqueles que argumentam a prática dos acordos executivos, em vista da necessidade de decisões rápidas, concluindo que a eventual demora na aprovação por parte do Legislativo decorre da indiferença do Executivo. ${ }^{15}$

A prática brasileira dos acordos em forma simplificada, concluídos sem a autorização expressa e específica do Poder Legislativo, entretanto, é bastante intensa no Brasil, como demonstram os inúmeros acordos concluídos pelo nosso país desta maneira, fato este que levou o Prof. CACHAPUZ DE MEDEIROs a observar "que o Itamaraty mantém o entendimento (...) de que o Brasil pode ser parte em acordos internacionais que não dependam da aprovação do Congresso Nacional". ${ }^{16}$

O lavor da Assembléia Constituinte, como assevera Grandino RodAs, "não foi levado em consideração no referente ao reconhecimento de direito da existência dos acordos em forma simplificada. Além de continuar não havendo previsão constitucional para tais tipos de acordo, o inc. VIII do art. 84 [da atual Constituição brasileira, de 1988], ao se referir não somente a tratados e convenções, mas até mesmo a atos internacionais, parece, em interpretação literal querer sujeitar qualquer ato internacional à aprovação parlamentar". ${ }^{17}$

$\mathrm{O}$ art. 80 da Constituição italiana, em redação semelhante, dispõe que: "Le Camere autorizzano con legge la ratifica dei trattati internazionali, che sono di natura politica o prevedono arbitrati o regolamenti giudiziari o importano variazioni del territorio od oneri alle finanze, o modificazioni di leggi". À semelhança da norma brasileira, insculpida no art. 49, I, da Carta de 1988, este dispositivo, segundo a doutrina italiana, tem o condão de submeter ao Parlamento "tutti i trattati internazionali, specificando le poche eccezioni che a contrario si desumono dall'attuale texto dell'art. 80; perché l'elencazione che ivi si legge, soprattutto a causa della grande elasticità della prima e dell'ultima categoria di trattati, lascia ben pochi trattati internazionali fuori della norma che dispone l'esame del Parlamento, dato che pochi sono i trattati non di natura politica o che non importano una modificazione alla legislazione interna". ${ }^{18}$ Mas a doutrina italiana reconhece as numerosas perplexidades decorrentes dos chamados acordos em forma simplificada, aperfeiçoados ao alvedrio do Poder Legislativo. A esse respeito, a Corte costituzionale italiana (sent. n. ${ }^{\circ}$ 295/1984) chegou a afirmar que para os acordos internacionais que incidem sobre aquelas matérias estabelecidas no art. 80 da 
Constituição, não fica dispensada para sua ratificação a aprovação legislativa, sem embargo da prática corrente de conclusão desses acordos também nesse País. ${ }^{19}$

\section{O relacionamento entre os poderes executivo e legislativo no procedimento de conclusão de tratados internacionais}

Toda a discussão acima, mostrada ainda que brevemente, bem reflete a complexidade do tema que estamos tratando. Mas, deixando de lado as discussões acerca dos acordos executivos, retomemos o raciocínio anterior, no que tange ao poder de celebrar tratados. Urge voltarmos à explicação de como o Poder Executivo se relaciona com o Legislativo, no que diz respeito à conclusão dos tratados internacionais em geral.

De acordo com a Constituição brasileira de 1988, “compete à União manter relações com Estados estrangeiros e participar de organizações internacionais" (art. 21, I). Ao Presidente da República é dada competência privativa para "celebrar tratados, convenções e atos internacionais, sujeitos a referendo do Congresso Nacional" (art. 84, VIII). O Congresso, por sua vez, tem competência exclusiva para "resolver definitivamente sobre tratados, acordos ou atos internacionais que acarretem encargos ou compromissos gravosos ao patrimônio nacional" (art. 49, I). A redação dos dispositivos manteve-se, na expressão de Grandino RodAs, fiel à nossa má tradição constitucional na matéria, "não tendo nem mesmo incorporado no texto, os poucos avanços contidos no projeto de Constituição da Comissão de Sistematização". ${ }^{20}$

O certo é que, enquanto cabe ao Poder Executivo presidir a política externa, ao Legislativo cumpre exercer o controle dos atos executivos, uma vez que àquele incumbe a defesa da Nação no cenário internacional. Por importar no comprometimento da soberania nacional, não pode o tratado produzir efeitos se não for seguido de aprovação pelo Congresso, que representa a vontade nacional. ${ }^{21}$ O Presidente da República, com a competência privativa que lhe dá a Carta Magna, assim, não age por delegação do Congresso, mas por direito próprio, como já ensinou Pontes de Miranda. ${ }^{22}$

Terminada a fase de negociação de um tratado, "o Presidente da República - que, como responsável pela dinâmica das relações exteriores, poderia não tê-la jamais iniciado, ou dela não ter feito parte, se coletiva, ou haver ainda, em qualquer caso, interrompido a participação negocial brasileira - está livre para dar curso, ou não, ao processo determinante do consentimento". ${ }^{23}$ Estando satisfeito com o acordo celebrado, o Chefe do Poder Executivo submete-o ao crivo do Parlamento, representativo da vontade da Nação, podendo, também, em caso de insatisfação, mandar arquivá-lo.

O Congresso Nacional, por sua vez, quando chamado a se manifestar, através da elaboração de decreto legislativo (CF, art. 59, VI), materializa o que 
ficou resolvido sobre os tratados, acordos ou atos internacionais. Não há edição de tal espécie normativa em caso de rejeição do tratado, caso em que apenas se comunica a decisão, mediante mensagem, ao Chefe do Poder Executivo. ${ }^{24}$

A partir da Constituição de 1946, abolindo a grande imprecisão existente no emprego desse termo, fixou-se, nos Regimentos Internos das Casas do Congresso Nacional, o uso da expressão decreto legislativo para denominar aqueles atos da competência exclusiva do Poder Legislativo, ou seja, aqueles atos não sujeitos à sanção presidencial. ${ }^{25}$

O decreto legislativo, assim, é espécie normativa aprovada pelo Legislativo sobre matéria de sua exclusiva competência ( $\mathrm{CF}$, art. 49), como a aprovação de tratados internacionais, o julgamento das contas do Presidente da República, ou ainda sobre assuntos de seu interesse interno. ${ }^{26} \mathrm{Um}$ único decreto pode, inclusive, aprovar mais de um tratado; mas, se o tratado anteriormente aprovado e devidamente ratificado, fora posteriormente denunciado, novo decreto legislativo se fará necessário em caso de nova aprovação do mesmo tratado. ${ }^{27}$

Sendo ele da competência exclusiva do Congresso Nacional, não está, por isso, sujeito à sanção presidencial, sujeitando-se apenas à promulgação do Presidente do Senado Federal. Aliás, são óbvios - no dizer de Francisco CAMPOS - os motivos pelos quais a Constituição não faz depender da sanção do Presidente da República as resoluções votadas pelo Poder Legislativo. A inutilidade da sanção do Presidente da República ou a sua inconveniência pode decorrer do fato de já haver ele manifestado sobre determinadas matérias seu acordo, ou por constituírem as mesmas apenas uma aprovação a atos já praticados pelo Presidente da República, ou, então, por se tratar de resoluções que se limitam a conceder ao Presidente da República uma autorização por ele próprio solicitada ao Poder Legislativo. ${ }^{28}$

Enfim, no que diz respeito ao Estado brasileiro, os tratados, acordos e convenções internacionais, para que sejam incorporados ao ordenamento interno, necessitam de prévia aprovação do Poder Legislativo, que exerce a função de controle e fiscalização dos atos do Executivo.

A competência ad referendum do Congresso, esclareça-se, limita-se à aprovação ou rejeição do texto convencional tão somente, não sendo admissível qualquer interferência no seu conteúdo. Não comporta, pois, emendas. ${ }^{29}$ Concordando o Congresso com a assinatura do tratado internacional, por meio do decreto legislativo, dá-se "carta branca" ao Presidente da República para ratificar a assinatura já depositada, ou mesmo aderir se já não o tenha feito.

A aprovação parlamentar pode ser retratada, desde que não tenha sido, ainda, o tratado ratificado pelo Presidente da República. Se o tratado ainda não se encontra ratificado, é dizer, se ainda não houve o comprometimento da Nação no cenário internacional (não importando saber se o tratado já entrou em vigor, internacionalmente, ou não), o Congresso, por decreto legislativo mesmo, pode revogar igual diploma que tenha anteriormente aprovado o acordo. ${ }^{30}$ 
Apesar de estar o decreto legislativo dentre as espécies normativas do art. 59 da Constituição, ou seja, sem embargo de estar compreendido no processo legislativo, "não tem ele o condão de transformar o acordo assinado pelo Executivo em norma a ser observada, quer na órbita interna, quer na internacional". ${ }^{31}$ Tal fato somente irá ocorrer com a posterior ratificação e promulgação do texto do tratado pelo Chefe do Poder Executivo, o que o faz por meio de decreto de execução. É que, dando a Carta ao Presidente da República a competência privativa para celebrar tratados, e sendo ele o representante do Estado na órbita internacional, sua também deverá ser a última palavra em matéria de ratificação.

A manifestação do Congresso Nacional só ganha foros de definitividade quando desaprova o texto do tratado anteriormente assinado pelo Chefe do Executivo, quando, então, o Presidente da República estará impedido de levar a efeito a conclusão do acordo, ratificando-o. ${ }^{32}$

Esse sistema de aprovação congressual dos tratados internacionais, aliás, foi adotado em inúmeros países do continente americano (cf. Constituição argentina, art. 75, inc. 22; Constituição da Venezuela, art. 154; Constituição de El Salvador, art. 131, n. ${ }^{\circ}$ 7; Constituição da Guatemala, art. 171; Constituição da República Oriental do Uruguai, art. 168, n. ${ }^{\circ} 20$; Constituição chilena, art. 50, n. ${ }^{\circ} 1$; Constituição da Colômbia, art. 164; e Constituição paraguaia, art. 141). No Uruguai, v.g., competia a Assembléia Geral (Congresso) aprovar e reprovar, por maioria absoluta, os tratados celebrados pelo Poder Executivo (cf. art. 85, 7. ${ }^{\circ} \mathrm{c} / \mathrm{c}$ art. 168, n. 20, da Constituição de 1967: "A competência para concluir e firmar tratados é do Presidente da República atuando com o Ministro das Relações Exteriores ou com o Conselho de Ministros, necessitando, para sua ratificação, de aprovação pelo Poder Legislativo"). A soberania legislativa uruguaia, lembrese, ganhou ênfase no art. $4 .^{\circ}$ de sua Constituição, verbis: "La soberanía en toda su plenitud existe radicalmente en la Nación, a la que compete el derecho exclusivo de estabelecer sus leyes, del modo que más adelante se expresará".

Interessante, a respeito da aprovação congressual, é o art. 164 da Constituição colombiana de 1991, reformada em 1997, que dispõe: "El Congreso dará prioridad al trámite de los proyectos de ley aprobatorios de los tratados sobre derechos humanos que sean sometidos a su consideración por el Gobierno".

Para alguns autores (como v.g. Paul Fauchille e Dionisio Anzilotti, na doutrina alienígena, e Pedro Calmon e Hildebrando Accioly, no Brasil), o tratado apenas assinado é tão-somente um "projeto de tratado", se não foi devidamente aprovado por uma resolução legislativa promulgada pelo Presidente do Senado. ${ }^{33}$ Essa doutrina é, entretanto, contestada por PonTES DE MIRANDA, para quem o tratado assinado já é tratado, muito embora ainda dependa de ratificação e de aprovação congressual, se essa é exigida pelo direito interno do País. ${ }^{34}$ Para o grande tratadista pátrio, o tratado internacional assinado, que prescinde de aprovação do Congresso 
Nacional, existe, mas antes de ser aprovado não entra no mundo jurídico como negócio jurídico perfeito. ${ }^{35}$

Em suma, ao Legislativo "é atribuída a incumbência de examinar, uma vez consumada a celebração do ato pelo Presidente, se tal decisão pode ser mantida, em nome do interesse nacional. A harmônica coordenação entre os Poderes Legislativo e Executivo da União, nesse assunto, decorre de preceito constitucional inscrito no art. 21, I, segundo o qual compete à União 'manter relações com Estados estrangeiros e participar de organizações internacionais" ${ }^{36} \mathrm{E}$ isto constitui tendência característica das Constituições contemporâneas, onde "a constitucionalidade da ratificação lato sensu (ratificação pelo Poder Executivo + aprovação pelo Poder Legislativo) é indispensável". ${ }^{37}$

Como se percebe, por conseguinte, estamos diante de um procedimento complexo dos poderes da União, onde, para a formalização dos tratados, participam sempre o Legislativo e o Executivo. ${ }^{38}$ Sem a participação desses dois órgãos estatais a realização do ato não se completa, no que se pode dizer que foi adotada pela Constituição de 1988, seguindo a tradição constitucional anterior, a teoria dos atos complexos, mais adequada, neste tema, aos princípios de direito público e ao regime democrático. ${ }^{39}$

O judiciário, neste processo, só atua depois de devidamente incorporado em nosso ordenamento o tratado internacional, cabendo ao Supremo Tribunal Federal, na qualidade de guardião da Constituição, julgar, mediante recurso extraordinário, as causas decididas em única ou última instância, "quando a decisão recorrida declarar a inconstitucionalidade de tratado ou lei federal" (CF, art. 102, III, b). Ao Superior Tribunal de Justiça, a Carta de 1988, por sua vez, atribui a competência para julgar, mediante recurso especial, as causas decididas, em única ou última instância, pelos Tribunais Regionais Federais ou pelos Tribunais dos Estados, "quando a decisão recorrida contrariar tratado ou lei federal, ou negarlhes vigência" (art. 105, III, a). Por fim, diz o art. 109 da Constituição de 1988 competir aos juízes federais processar e julgar "as causas fundadas em tratado ou contrato da União com Estado estrangeiro ou organismo internacional" (inc. III), bem como "os crimes previstos em tratado ou convenção internacional, quando, iniciada a execução no País, o resultado tenha ou devesse ter ocorrido no estrangeiro, ou reciprocamente" (inc. V).

Tudo o que não pode o Presidente da República fazer é manifestar definitivamente o consentimento sem o "abono" do Congresso Nacional. ${ }^{40}$ Embora seja ele o titular da dinâmica das relações internacionais, cabendo-lhe decidir tanto sobre a conveniência de iniciar negociações, como a de ratificar o ato internacional já concluído, o abono do Poder Legislativo, sob a forma de aprovação congressual é, via de regra, necessário. Antes de submetido o tratado internacional à aprovação do Congresso, os poderes que têm os Embaixadores, ordinário e extraordinários, e os Ministros Plenipotenciários é apenas o de empenhar o ato do Poder Executivo 
e não o de criar a obrigação de ser mantido o que foi assinado. ${ }^{41}$ Esse abono parlamentar, contudo, como ensina JosÉ Francisco REZEK, "não o obriga à ratificação. Isto significa, noutras palavras, que a vontade nacional, afirmativa quanto à assunção de um compromisso externo, repousa sobre a vontade conjugada dos dois poderes políticos. A vontade individualizada de cada um deles é necessária, porém não suficiente" [grifos do original]. ${ }^{42}$

Nesse mesmo sentido, a lição de MirTô FraGa, in verbis: "Com a simples concordância do Congresso, completa-se, apenas, uma das fases de sua elaboração. O decreto legislativo é autorização ao Executivo para concluir o acordo e é a aquiescência do Congresso à matéria nele contida. (...) O decreto-legislativo, sem o decreto de promulgação do Presidente da República, após as demais formalidades, nenhum valor normativo possui, nesse caso, segundo a corrente dominante no Brasil. Não é necessário que o Poder Legislativo elabore novo ato, uma lei, repetindo o texto do tratado para que ele passe a ter vigência na ordem interna. De acordo com a técnica, no Brasil, basta o decreto do chefe do Poder Executivo promulgando o tratado". ${ }^{43}$

Para Pontes de Miranda, “o Presidente da República pode pedir a aprovação antes da ratificação perante o Estado ou os Estados contraentes, como pode ratificar, frisando que depende de aprovação do Congresso Nacional. Aliás, se não o diz, é isso que se há de entender, porque todos os Estados devem conhecer as Constituições dos Estados com que concluem tratados, convenções ou acordos". ${ }^{44}$

Como se depreende da lição Louis Henkin, o poder de celebrar tratados como é concebido e como de fato se opera - é uma autêntica expressão da sistemática de checks and balances, ou seja, do sistema de "freios e contrapesos". Ao atribuir o poder de celebrar tratados ao Poder Executivo, mas apenas mediante o referendo do Legislativo, busca-se limitar e descentralizar o poder de celebrar tratados, prevenindo o abuso desse poder..$^{45}$

\section{O verdadeiro papel do Congresso Nacional no procedimento de conclusão de tratados internacionais}

Há muita confusão por parte da generalidade doutrinária em relação ao verdadeiro papel do Congresso Nacional no procedimento de celebração de tratados internacionais, em grande parte causada por má interpretação do texto constitucional.

Diz a Carta de 1988 competir exclusivamente ao Congresso Nacional "resolver definitivamente sobre tratados, acordos ou atos internacionais que acarretem encargos ou compromissos gravosos ao patrimônio nacional" (art. 49, I). E a partir deste dispositivo, grande parte da doutrina leciona, primeiro, no sentido de que somente os tratados "que acarretem encargos ou compromissos gravosos ao patrimônio nacional" devem passar pelo crivo do Parlamento e, segundo, 
no de que o Congresso Nacional, através do referendo, ratifica (o que não é verdade) tratados internacionais. ${ }^{46}$

O equívoco, entretanto, é tamanho. A interpretação do que vem a ser "resolver definitivamente" e do que se consideram "encargos ou compromissos gravosos ao patrimônio nacional", no que diz respeito ao papel do Congresso Nacional no procedimento de aprovação de tratados internacionais, deve ser cotejada com a competência do Chefe do Poder Executivo para "celebrar tratados, convenções e atos internacionais", estabelecida pelo inciso VIII do art. 84 da Carta de 1988.

Habilitado a ratificar tratados internacionais está somente o Presidente da República e ninguém mais. É sua, nesta sede, a última palavra. Ao Parlamento incumbe aprovar ou rejeitar o tratado assinado pelo Executivo, mais nada. ${ }^{47} \mathrm{~A}$ expressão "resolver definitivamente sobre tratados", assim, deve ser entendida em termos, não se podendo dar a ela um significado acima de seu real alcance. ${ }^{48}$ E isto porque, "resolver definitivamente" no sistema brasileiro, não significa ratificação, que é ato próprio do Chefe do Executivo, responsável pela dinâmica das relações internacionais, a quem cabe decidir tanto sobre a conveniência de iniciar as negociações, como a de ratificar o ato internacional já concluído. Por conseguinte, incumbe ao Parlamento aprovar ou não os tratados internacionais submetidos à sua apreciação, e ao Chefe do Executivo ratificá-los, se aprovados pelo Congresso Nacional.

O Parlamento, então, só resolve definitivamente sobre tratados quando os rejeita, ficando o Executivo, neste caso, impedido de ratificar o acordo ${ }^{49} \mathrm{Em}$ caso de aprovação congressual, quem resolve de modo definitivo é o Chefe do Poder Executivo, ao ratificar ou não o tratado internacional, segundo critérios de conveniência e oportunidade.

Por este motivo, a expressão resolver definitivamente, que, de resto, vem se mantendo até hoje nas Constituições brasileiras, tem sido considerada das mais impróprias dentre as que respeitam à matéria. CACHAPUZ DE MedeIRos, julgou-a como "a mais inadequada, posto que a decisão efetivamente definitiva incumbe ao Presidente da República, que pode ou não ratificar os tratados internacionais, depois destes terem sido aprovados pelo Congresso". ${ }^{50}$

A manifestação do Congresso Nacional, assim, só ganha foros de definitividade quando desaprova o texto do tratado anteriormente assinado, quando, então, o Presidente da República estará impedido de levar a efeito a ratificação. ${ }^{51}$ Mas, se aprovou o tratado submetido à sua apreciação, a última palavra é do Chefe do Executivo que tem a discricionariedade de ratificá-lo ou não, segundo o que julgar mais conveniente.

Por isso, é bom que se esclareça, em definitivo, que o Congresso Nacional não ratifica nenhum tipo de ato internacional. Em verdade, através de decreto legislativo, o nosso parlamento federal autoriza a ratificação, que é ato próprio do 
Chefe do Poder Executivo, a quem compete privativamente, nos termos da Constituição da República (art. 84, VIII), celebrar tratados e acordos internacionais. É dizer, o Congresso Nacional apenas aprova ou não o texto convencional - fazendoo por meio de decreto legislativo -, de forma que a aprovação dada pelo Poder Legislativo, em relação ao tratado, não tem o condão de torná-lo obrigatório, pois o Presidente da República, após isso, pode ou não, segundo o que for mais conveniente aos interesses da Nação, ratificá-lo.

A Constituição da República de El Salvador, de 1982, parece confundir-se a esse respeito, quando estabelece no seu art. 131 (7) que compete à Assembléia Legislativa "ratificar os tratados e pactos celebrados pelo Executivo com outros Estados ou organismos internacionais, ou denegar sua ratificação". Quer nos parecer, s.m.j., que dentre as Constituições do continente americano, esta é a única a fazer confusão a respeito do assunto, impropriamente chamando de ratificação ou que deveria chamar de aprovação. Correta, a esse respeito, está a Carta da República da Guatemala de 1985, que, no seu art. 171 (letra l), dispõe competir ao Congresso Nacional "aprovar, antes de sua ratificação, convênios ou qualquer acordo internacional", nas matérias que especifica, bem como a Constituição da República da Venezuela, que, no seu art. 154, estabelece que os tratados celebrados pela República "deben ser aprobados por la Asamblea Nacional antes de su ratificación por el Presidente o Presidenta de la República, a excepción de aquellos mediante los cuales se trate de ejecutar o perfeccionar obligaciones preexistentes de la República, aplicar principios expresamente reconocidos por ella, ejecutar actos ordinarios en las relaciones internacionales o ejercer facultades que la ley atribuya expresamente al Ejecutivo Nacional". No mesmo sentido a Constituição da República Oriental do Uruguai, de 1997, art. 168, alínea 20: “A1 Presidente de la República, actuando con el Ministro o Ministros respectivos, o con el Consejo de Ministros, corresponde concluir y suscribir tratados, necesitando para ratificarlos la aprobación del Poder Legislativo"; e também, a Constituição chilena, de 1980 (com as reformas de 1997), art. 50 (1): "Son atribuciones exclusivas del Congreso (...) aprobar o desechar los tratados internacionales que le presentare el Presidente de la República antes de su ratificación. La aprobación de un tratado se someterá a los trámites de una ley".

Em Parecer proferido na condição de Consultor Jurídico do Itamaraty, sob a égide da Constituição de 1946, HiLDEBRANDO ACCIOLY, a esse respeito, analisou, tanto no aspecto do direito internacional, como no do direito interno (ou constitucional), a questão da faculdade do Presidente da República de ratificar ou não tratados, e o fez nestes termos: 1) Sob o aspecto do direito internacional, "é princípio corrente, já consignado até em convenção internacional (art. 7. ${ }^{\circ}$ da Convenção de Havana, de 1928), que a ratificação de um tratado pode ser livremente recusada por qualquer de suas partes contratantes. Realmente, ou se considere a ratificação como a confirmação explícita, dada pela autoridade 
competente do Estado, do ato assinado por seu representante, ou se considere, como quer ANZILOTTI, como a verdadeira declaração da vontade de estipular - é sabido que ela não constitui mera formalidade, sem importância, e que cada parte contratante tem a plena liberdade de a dar ou de a recusar. A assinatura ou acordo dos plenipotenciários é apenas - conforme escrevi em meu Tratado de Direito Internacional Público - um primeiro ato, após o qual os órgãos competentes do Estado vão apreciar a importância e os efeitos ou conseqüências do tratado. Essa apreciação, entre nós, cabe em parte ao Poder Legislativo, mas não pode deixar de caber igualmente ao Poder Executivo ou, antes, ao Presidente da República, que é o órgão ao qual incumbe a representação do Estado e aquele a quem compete manter as relações do país com os Estados estrangeiros. Dessa apreciação, pode resultar a confirmação ou a rejeição do tratado. Internacionalmente, a primeira hipótese é representada pela ratificação, expressa pelo Presidente da República. Pouco importa para a outra ou as outras partes contratantes que um dos órgãos do Estado (no caso, o Poder Legislativo) já tenha dado sua aquiescência ao tratado. O que vale é que o Poder representativo do Estado, ou seja, o Executivo, o ratifique. Assim, a potência ou potências estrangeiras não têm propriamente que indagar se já se verificou ou não a aprovação do ato pelo Congresso Nacional: o que lhe ou lhes importa é a ratificação pelo Chefe do Estado; 2) Do ponto de vista constitucional, não vejo onde exista a obrigação do Poder Executivo ratificar um tratado, como conseqüência necessária da aprovação do mesmo pelo Congresso Nacional. É verdade que a Constituição Federal, em seu art. 66, n. ${ }^{\circ} 1$ [hoje, art. 49, I, da Carta de 1988], declara ser da competência exclusiva do Congresso Nacional resolver definitivamente sobre tratados e convenções celebrados com os Estados estrangeiros pelo Presidente da República. Parece-me, porém, que essa estipulação deve ser entendida no sentido de que o tratado - celebrado como deve ser, pelo Presidente da República (por meio de delegado seu) - não está completo, não pode ser definitivo, sem a aprovação do Congresso Nacional. Aquela expressão significa, pois, que o tratado celebrado pelo Poder Executivo, não pode ser confirmado ou entrar em vigor, sem a aprovação do Congresso Nacional: mas não quererá dizer que essa aprovação obrigue o Presidente da República a confirmar o tratado. E não quererá dizer isso, não só porque seria, então, desnecessária a ratificação, mas também porque o órgão das relações exteriores do Estado, aquele a quem compete privativamente manter relações com Estados estrangeiros, é o Presidente da Republica - que, por isso mesmo, se acha mais habilitado, do que o Congresso, a saber se as circunstâncias aconselham ou não o uso da faculdade da ratificação. Por outro lado, essa interpretação lógica é confirmada implicitamente por outra disposição da Constituição Federal. De fato, determina esta, em seu art. 37, n. ${ }^{\text {o }}$ VII [hoje, art. 84, VIII, da Carta de 1988], que ao Presidente da República compete privativamente celebrar tratados e convenções internacionais ad referendum do Congresso Nacional; donde se deve concluir que o papel do Congresso, no caso, é 
apenas o de aprovar ou rejeitar o ato internacional em apreço, - isto é, autorizar ou não a sua ratificação, ou seja resolver definitivamente sobre o dito ato. Assim, o Presidente da República assina o tratado, por delegado seu, mediante uma condição: a de submeter ao Congresso nacional o texto assinado. Depois do exame pelo Congresso, estará o Presidente habilitado, ou não, a confirmar ou ratificar o ato em causa. A rejeição pelo congresso impede a ratificação; a aprovação permite-a, mas não a torna obrigatória". ${ }^{2}$

O Congresso Nacional - repita-se - não ratifica tratados. Quem os ratifica é o Chefe do Poder Executivo, é dizer, o Presidente da República. Sem este ato presidencial, e posterior promulgação, não existe tratado válido a obrigar a Nação, quer internacionalmente (falta de ratificação), quer internamente (falta de promulgação, à exceção dos tratados de proteção dos direitos humanos, cuja aplicação é imediata desde a ratificação, pela interpretação dos $\S \S 1 .^{\circ}$ e $2 .^{\circ}$ do art. 5. ${ }^{\circ}$ da Carta de 1988).

A lição do Prof. Antônio Paulo Cachapuz de Medeiros, é tão clara a esse respeito, que merece ser transcrita. Diz o insigne Professor:

"Os Parlamentos não ratificam tratados internacionais. Somente os examinam, autorizando ou não o Poder Executivo a comprometer o Estado."

"A ratificação, por conseguinte, é ato privativo do Chefe do Executivo, pelo qual este confirma às outras partes, em caráter definitivo, a disposição do Estado de cumprir um tratado internacional."

"Assim, convém fique nítido que a aprovação dada pelo Poder Legislativo não torna um tratado obrigatório, pois o Executivo tem ainda a liberdade de ratificá-lo ou não, conforme julgar mais conveniente."

"Essa regra é universal, sendo entendimento unânime que a decisão de ratificar cabe ao mesmo Poder em nome do qual foram assinados os tratados."

"Alega-se, basicamente, que, passado algum tempo da assinatura do acordo internacional, podem ter mudado as circunstâncias políticas, e a nova conjuntura não recomendar mais o engajamento do Estado. (...)"

"Um tratado entra em vigor internacionalmente no instante em que os Estados signatários se comunicam reciprocamente a existência dos instrumentos de ratificação."

"Tal notificação dá-se de duas formas: troca ou depósito dos aludidos instrumentos."

"A troca ocorre, em geral, nos acordos bilaterais e o depósito nos multilaterais."

"Depois de ratificado devidamente, o ato internacional precisa ser promulgado pelo Presidente da República e só então se incorpora à nossa legislação interna."

"Para evitar confusões, convém frisar que essa promulgação pelo Executivo, através de decreto, incorporando o ato internacional à legislação interna, não deve ser confundida com a promulgação da aprovação do ato internacional 
pelo Congresso, que assume a forma de um decreto legislativo, firmado pelo Presidente do Senado" [grifos nossos]. ${ }^{53}$

Como salienta João Hermes Pereira de Araújo, "o fato de ter sido o tratado aprovado por decreto legislativo não o exime da promulgação, uma vez que um ato aprovado poderá nunca entrar em vigor, pois, se a aprovação legislativa condiciona a ratificação, não a torna obrigatória e, muito menos, pode ter efeito junto à outra parte contratante que, até o momento da troca de ratificações, é livre de o fazer". ${ }^{54}$ É também a lição de LuIz FLÁvio GoMES, para quem, só depois da aprovação do tratado pelo Congresso, na forma de decreto legislativo, é possível a sua ratificação (ou adesão). Mas a simples ratificação, entretanto, "não basta para a vigência do tratado, pois ainda é necessária sua promulgação por Decreto presidencial e publicação. Depois de publicado o tratado tem intrinsecamente força normativa e revoga as disposições ordinárias em contrário". ${ }^{55}$

O ordenamento brasileiro é integralmente ostensivo nesta sede. De forma que não pode ficar excluída a publicação do acervo normativo nacional, seja ele composto por tratados internacionais ou por produção doméstica. ${ }^{56}$ Vige, de resto, o princípio da publicidade também aqui, quando estão em jogo normas provenientes de tratados internacionais pelo País ratificados. Apenas aqui, faz-se a observação de que o que foi dito vige apenas em relação aos tratados internacionais convencionais, reguladores das relações recíprocas entre os Estados. Somente não vige o afirmado no que toca aos tratados internacionais de proteção dos direitos humanos, por terem aplicação imediata no ordenamento brasileiro $\left(\mathrm{CF}\right.$, art. 5. $\left.{ }^{\circ}, \S 1 .^{\circ}\right) . .^{57}$

Por fim, resta a análise da parte final do inciso I do art. 49 da Constituição de 1988.

De fato, a Constituição complementa, ne (art. 84, VIII) disse competir ao Presidente da República celebrar tratados, convenções e atos internacionais, sujeitos todos ao referendo do Congresso Nacional.

Qual seria a interpretação correta desses preceitos? Há conflito entre ambos os dispositivos? Estariam aqueles tratados que não acarretem encargos ou compromissos gravosos ao patrimônio nacional, isentos do referendo parlamentar?

Não é essa, ao que nos parece, a melhor exegese. A antinomia entre os artigos 49, I e 84, VIII da Carta de 1988, é apenas aparente. O art. 84, VIII da Constituição impõe que todos os tratados celebrados pelo Chefe do Executivo, devem ser submetidos ao referendo do Congresso Nacional. E, com base nisto, deve-se interpretar o art. 49, I da Constituição extensivamente, tendo em vista ter o legislador constituinte dito menos do que pretendia: lex minus dixit quam voluit. O desejo da Assembléia Nacional Constituinte, evidentemente, foi o de submeter todos os atos internacionais ao referendo do Poder Legislativo, e não apenas alguns deles. 
Por isso, estamos com o Prof. Cachapuz de Medeiros, que "do ponto de vista histórico-teleológico, a conclusão só pode ser que o legislador constituinte desejou estabelecer a obrigatoriedade do assentimento do Congresso para [todos] os tratados internacionais, dando ênfase para aqueles que acarretem encargos, gravames, [ou] ônus financeiros, para o patrimônio nacional". De outra banda, "do ponto de vista lógico-sistemático, há que considerar que os dispositivos em questão fazem parte do mesmo título da Constituição (Da Organização dos Poderes) e são como que as duas faces de uma mesma moeda: o artigo 84, VIII, confere ao Presidente da República o poder de celebrar tratados, convenções e atos internacionais, mas especifica que estão todos sujeitos a referendo do Congresso Nacional; o artigo 49, I, destaca que os tratados, acordos ou atos que acarretem encargos ou compromissos gravosos ao patrimônio nacional, precisam ser aprovados pelo Congresso" [grifos nossos]..$^{58}$

É o resultado que se extrai dos modernos métodos de interpretação.

Em suma, "no direito brasileiro, dá a Constituição Federal competência privativa ao Presidente da República, para celebrar tratados e convenções internacionais ad referendum do Congresso Nacional (...). Por outro lado, tem o Congresso Nacional competência exclusiva para resolver definitivamente sobre tratados e convenções celebrados com os Estados estrangeiros pelo Presidente da República (...). Assim, celebrado o tratado ou convenção por representante do Poder Executivo, aprovado pelo Congresso Nacional e promulgado pelo Presidente da República, com a publicação do texto, em português no órgão de imprensa oficial, tem-se como integrada a norma da convenção internacional no direito interno". 59

Mas frise-se que o que foi dito acima, no sentido de que depois de devidamente ratificado, o tratado internacional precisa ser promulgado pelo Presidente da República para só então se incorporar à nossa legislação interna, não vigora quando o tratado ratificado é de proteção dos direitos humanos. Neste caso especial, basta a ratificação para que o tratado internacional (protetivo dos direitos da pessoa humana - repita-se) passe a produzir seus efeitos tanto no plano interno como no plano internacional, dispensando-se a edição de decreto executivo para tal. ${ }^{60}$

\section{Procedimento parlamentar: etapas internas das Casas do Congresso Nacional}

O Congresso Nacional, para a apreciação da viabilidade de se aderir aos tratados internacionais, segue algumas etapas internas que merecem ser analisadas com alguns pormenores.

No Legislativo, em primeiro lugar, ocorrerá a recepção da mensagem do Presidente da República, acompanhada da Exposição de Motivos (EM) do Ministro 
das Relações Exteriores, a ele endereçada, juntamente com o texto de inteiro teor do tratado internacional submetido à apreciação. ${ }^{61}$ Referida mensagem terá sua tramitação iniciada na Câmara dos Deputados, pois por expressa determinação constitucional (art. 64), "a discussão e votação dos projetos de lei de iniciativa do Presidente da República (...) terão início na Câmara dos Deputados”.

Assim, a matéria é discutida e votada separadamente, a começar pela Câmara dos Deputados. Somente considerar-se-á aprovada pelo Congresso com aprovação de uma e outra de suas duas casas, de forma que uma "eventual desaprovação no âmbito da Câmara dos Deputados põe termo ao processo, não havendo por que levar a questão ao Senado em tais circunstâncias". ${ }^{62}$

Em plenário ser-lhe-á dada a leitura, de modo a que, em obediência ao princípio da publicidade, tomem dela os Senhores Deputados conhecimento. Forma-se então um processo (que recebe a designação de "Mensagem"), com número próprio, e que, por força do art. 32, X do Regimento Interno da Câmara dos Deputados, será remetido à Comissão de Relações Exteriores. Esta Comissão, após o exame do texto do tratado por um relator designado dentre seus integrantes, aprecia o relatório dando um parecer. Deve este parecer apresentar um projeto de decreto legislativo, que será, ainda, submetido ao crivo da Comissão de Constituição, Justiça e Redação (art. 32, III, do Regimento Interno) à qual compete examinar os "aspectos constitucional, legal, jurídico, regimental e de técnica legislativa de projetos, emendas ou substitutivos sujeitos à apreciação da Câmara ou de suas comissões". Aprovado o projeto pelas Comissões, será ele submetido à votação em plenário. Aprovado o projeto, em turno único, terá ele sua redação final apresentada pela comissão de Constituição e Justiça (art. 32, III, "q"). Aprovada a redação final, passa o projeto, nos termos do art. 65 da Constituição, à apreciação do Senado Federal. Após lido e publicado o projeto, será ele despachado à comissão de Relações Exteriores e Defesa Nacional, onde, de acordo com o que dispõe o Regimento Interno do Senado Federal (art. 103, I), é a Comissão competente para examinar as "proposições referentes aos atos e relações internacionais" e aos "assuntos referentes à Organização das Nações Unidas e entidades internacionais de qualquer natureza". ${ }^{63}$

Em cada uma das Casas é possível a apresentação de emendas aos projetos submetidos à apreciação. Essas emendas, frise-se, dizem respeito estritamente ao projeto de decreto legislativo, jamais ao texto dos tratados submetidos à apreciação, insuscetíveis de qualquer mudança. Entende-se, entretanto, que simples correções de forma, como algum ajuste redacional no texto, que não atinge o conteúdo do projeto, dispensa o retorno à Câmara para o reexame. Somente em se tratando de mudança de mérito é que o reexame fica obrigatório (CF, art. 65 , parágrafo único). ${ }^{64}$

Estando concluído, no Senado, o exame na Comissão de Relações Exteriores e Defesa Nacional, "o projeto fica pronto para ser incluído na ordem do dia do plenário. Aprovado em plenário, em turno único, sem emendas, fica dispensada 
a redação final e o texto do projeto de decreto legislativo é dado como definitivamente aprovado, seguindo à promulgação", cuja prerrogativa é "do Presidente do Senado Federal, que é o [Presidente] do Congresso Nacional, conforme preceitua o art. 57, $\S 5 .^{\circ}$, da Constituição" ${ }^{65}$ Promulgado o decreto será o mesmo numerado (pela Secretaria Geral da Mesa do Senado) e publicado no Diário do Congresso Nacional e no Diário Oficial da União.

Em suma, formalizados os tratados pelos agentes diplomáticos, denominados plenipotenciários, que representam o Poder Executivo, tornam-se eles obrigatórios somente após ratificados pelo Presidente da República (chefe do Executivo). Mas, tal ratificação somente terá efeito depois de cumprida fase de apreciação e autorização pelo Congresso Nacional (Poder Legislativo).

A Constituição de 1988, contudo, ao estabelecer apenas esses dois dispositivos supracitados, "traz uma sistemática lacunosa, falha e imperfeita, ao não prever, por exemplo, prazo para que o Presidente da República encaminhe ao Congresso o tratado por ele assinado (emblemático é o caso da Convenção de Viena sobre o Direito dos Tratados, que foi assinada em 1969 e encaminhada à apreciação do Congresso apenas em 1992). Não há ainda previsão de prazo para que o Congresso aprecie o tratado assinado e nem mesmo previsão de prazo para que o Presidente da República ratifique o tratado, se aprovado pelo Congresso" ${ }^{66}$

O art. 47, parágrafo único, da Constituição de 1967 fixava prazo de quinze dias para que o Poder Executivo enviasse ao Congresso Nacional qualquer tratado, convenção ou acordo internacional. A emenda n. ${ }^{\circ} 1$ de 17 de outubro de 1969, retirou o parágrafo único do art. 47 (correspondente ao art. 44 da Carta emendada). Segundo a lição de Pontes DE Miranda, "nenhuma razão justifica que o Poder Executivo não envie [ao Congresso Nacional], desde logo, após a assinatura pelo Presidente da República, ou após a assinatura em ratificação, o tratado (senso estrito), a convenção ou o acôrdo". ${ }^{67}$

Ademais, à exceção dos tratados de direitos humanos $\left(\mathrm{CF}, \operatorname{art} .5^{\circ}, \S 2 .^{\circ}\right), \mathrm{o}$ texto constitucional de 1988, em nenhum de seus dispositivos estatuiu, de forma clara, qual a posição hierárquica do direito internacional perante o direito interno brasileiro. A Carta de 1988, assim, infensa à importância da questão e fazendo tábula rasa dos trabalhos da Assembléia Constituinte, preferiu, nas palavras de Grandino RoDAs, "passar ao largo do problema". ${ }^{68}$

Sem embargo do número excessivamente alto de Constituições que regeram o País, em 178 anos de independência, inobstante a baixa média da sua vigência (sobretudo se se reportar, apenas ao período republicano), o que se verifica é "que pouca, ou nenhuma, foi a evolução, no que respeita ao disciplinamento das relações entre o direito interno e o Direito Internacional, permanecendo, hoje, situação quase idêntica à de 1891". ${ }^{69}$ A solução para o conflito entre tratados internacionais e leis internas, face à ausência de dispositivos constitucionais que garantam unidade $\mathrm{e}$ coerência à ordem jurídica estatal, fica assim, no mais das vezes, comprometida. 
Dessa forma, não havendo menção expressa ao sistema adotado para a incorporação de tratados (monista ou dualista), controvertida fica a questão de se saber se tais tratados se incorporam automaticamente em nosso ordenamento ou, ao contrário, se é necessária a edição de decreto de execução materializando seus efeitos no plano interno.

\section{Procedimento brasileiro para a entrada em vigor dos tratados}

Promulgado o decreto legislativo pelo Presidente do Senado Federal, e publicado o mesmo tanto no Diário do Congresso Nacional como no Diário Oficial da União, iniciam-se os procedimentos cabíveis para a sua entrada em vigor no ordenamento jurídico pátrio.

A entrada em vigor dos atos bilaterais pode se dar, tanto pela troca de informações, como pela troca de cartas de ratificação.

Quando a entrada em vigor é feita pela primeira modalidade, pode-se passar, de imediato, nota à Embaixada da outra parte acreditada junto ao Governo brasileiro. Não existindo em território nacional Embaixada da outra parte, a nota é passada pela Embaixada do Brasil acreditada junto à outra parte. Em último caso, a notificação é passada pela Missão brasileira junto à ONU à Missão da outra parte contratante.

Caso a entrada em vigor se dê por troca de instrumentos de ratificação, aguarda-se a conclusão dos trâmites internos de aprovação por ambas as partes, para somente então realizar-se a cerimônia da troca dos respectivos instrumentos. Uma ata ou protocolo, consignando-se a troca dos instrumentos, é lavrado em dois exemplares, nos respectivos idiomas dos dois contratantes ou num terceiro (geralmente, o francês), assinado e selado pelos plenipotenciários especialmente designados para a troca. ${ }^{70}$

A entrada em vigor dos atos multilaterais, por sua vez, exige um procedimento um pouco mais complexo. Neste caso, publicado o decreto legislativo, para que o ato multilateral entre em vigor internamente no Brasil, é necessário seja ele ratificado. Ou seja, após a assinatura do tratado, e posterior aprovação pelo Congresso Nacional, requer-se seja depositado o instrumento de ratificação, da parte brasileira, junto ao Governo ou organismo internacional responsável pelas funções de depositário. Pode ocorrer, após isso, que se tenha que aguardar algum decurso de prazo, caso haja estipulação nesse sentido, para que o ato possa, a partir do término do mesmo, começar a produzir seus efeitos internamente.

Depositado o instrumento de ratificação junto ao Governo ou organismo responsável pelas funções de depositário, a prática brasileira, seguindo a tradição lusitana, tem exigido que deva o Presidente da República, a quem a Constituição dá competência privativa para celebrar tratados, convenções e atos internacionais (art. 84, VIII), expedir um decreto de execução, promulgando e publicando no 
Diário Oficial da União o conteúdo dos tratados, materializando-os, assim, internamente.

A promulgação e a publicação, no sistema brasileiro, compõem a fase integratória da eficácia da lei, vez que atesta a sua adoção pelo Poder Legislativo, certifica a existência de seu texto e afirma, finalmente, seu valor imperativo e executório.

A partir da publicação, passa o tratado a integrar o acervo normativo nacional, "habilitando-se ao cumprimento por particulares e governantes, e à garantia de vigência pelo Judiciário". ${ }^{71}$

No Brasil promulgam-se todos os tratados aprovados pelo Congresso Nacional, valendo como ato de publicidade. Publicam-se apenas, no Diário Oficial da União, aqueles que prescindiram de referendo parlamentar e de ratificação do Presidente da República, a exemplo dos "acordos executivos", cuja publicação no Diário Oficial é autorizada pelo Ministro das Relações Exteriores e efetivada pela Divisão de Atos Internacionais do Itamaraty. ${ }^{72}$

Frise-se que nenhuma das Constituições brasileiras jamais trouxe, taxativamente, dispositivo expresso determinando esse procedimento. ${ }^{73}$ Segundo KeLSEN, o direito internacional só necessita de transformação em direito interno quando essa necessidade é formulada pela Constituição. Se a Carta Magna silencia a respeito, os tribunais nacionais estão aptos a aplicar, imediatamente, os tratados celebrados, a partir da ratificação. Neste caso, seria supérflua a promulgação, em virtude de inexistência de mandamento constitucional regulador da matéria. ${ }^{74}$

Para alguns autores, como REzeK, o decreto de promulgação é produto da praxe, tão antiga quanto a independência e os primeiros exercícios convencionais do Império. Cuida-se de um decreto, tão somente porque os atos do chefe de Estado costumam ter esse nome, e por mais nenhum outro motivo. ${ }^{75}$ Outros entendem, entretanto, que a promulgação de tratados internacionais decorre do comando constitucional do art. 84, que diz competir privativamente ao Presidente da República sancionar, promulgar e fazer publicar as leis, bem como expedir decretos e regulamentos para sua fiel execução (inc. IV), emprestando-se ao vocábulo lei sentido mais amplo, de forma a entendê-lo como fonte positiva do direito. É a posição de MiRTô FragA, para quem as Constituições brasileiras, quando se referem à promulgação de lei, fazem-no dando ao vocábulo sentido amplo, que, em alguns casos, não se completa com a sanção presidencial. Cita a autora o $\S 6 .^{\circ}$ do art. 59 da Carta revogada onde se expressava que "nos casos do artigo 44, após a aprovação final, a lei será promulgada pelo Presidente do Senado Federal", concluindo que, referindo-se o art. 44 à matéria de competência exclusiva do Congresso Nacional e não comportando sanção ou veto, é porque, em conseqüência, não se trata de lei em sentido estrito. ${ }^{76}$

A Constituição brasileira de 1988, neste tema, consagra o princípio da legalidade, pelo qual "ninguém será obrigado a fazer ou deixar de fazer alguma 
coisa senão em virtude de lei" (art. 5. ${ }^{\circ}$, II), dizendo, ainda, competir privativamente ao Presidente da República "sancionar, promulgar e fazer publicar as leis, bem como expedir decretos e regulamentos para sua fiel execução" (art. 84, IV).

Nada mais é o decreto de execução presidencial do que "o atestado de existência de uma regra jurídica, regularmente concluída, em obediência ao processo específico, instituído na Lei Maior". ${ }^{77}$ Sem embargo de terem as nossas Constituições silenciado a respeito da promulgação de tratados, tal prática, como lembra MAROTTA Rangel, tem persistido entre nós, desde o Império, e a rigor, desde a celebração do primeiro ato internacional pelo nosso País celebrado. ${ }^{78}$

A promulgação tem por finalidade, pois, atestar que o ato internacional já existe e que foram cumpridas todas as formalidades internas para sua celebração. Indica, ademais que o compromisso internacionalmente firmado já é juridicamente exigível, obrigando a todos sua observância (Executivo, Legislativo e também o Judiciário).

A Convenção de Havana sobre Tratados Internacionais, de 1928, ainda em vigor no Brasil, estabelece no seu art. $4 .^{\circ}$ que os tratados "serão publicados imediatamente depois da troca das ratificações", mas acrescenta que "a omissão no cumprimento desta obrigação internacional, não prejudicará a vigência dos tratados, nem a exigibilidade das obrigações nele contidas”.

A promulgação não integra o processo legislativo. Ao contrário: o que se promulga já é lei. Desta sorte, é errôneo afirmar-se que "o tratado promulgado por decreto do Executivo deixa, no âmbito interno do Estado, de ser Direito Internacional, para ser disposição legislativa interna. $\mathrm{O}$ que acontece é o seguinte: assinado o tratado, aprovado pelo legislativo, ratificado pelo Executivo, ele passa, conforme o que se estabeleceu no seu próprio texto, a vigorar na órbita internacional. Os indivíduos, porém, para acatá-lo e os Tribunais para aplicá-lo precisam ter conhecimento de que ele existe. Pela promulgação, o Chefe do Poder Executivo apenas declara, atesta, solenemente, que foram cumpridas as formalidades exigidas para que o ato normativo se completasse". ${ }^{79}$

Mas, para que a norma jurídica se considere efetivamente promulgada é indispensável sua publicação, dando conhecimento à população de sua existência. De sorte que, como só é obrigatória a norma que se conhece (e a publicação faz presumir este conhecimento), o tratado aprovado somente será obrigatório a partir da inserção da norma promulgada no Diário oficial da União, contendo em apenso o texto do tratado. Com a publicação do tratado, busca-se, assim, dar publicidade de seu conteúdo a todos os nacionais do País, e fixar o seu início de vigência. Quando silentes a este último propósito, fazem operar o comando do art. 1. ${ }^{\circ}$ da Lei de Introdução do Código Civil, que dá quarenta e cinco dias de prazo para o início desta vigência. ${ }^{80}$

Este procedimento é regulado, no Brasil, pelo Decreto . $^{\circ}$ 96.671/88, que assim estabelece nos arts. $1^{\circ}, 2^{\circ}$ e $3^{\circ}$ : 
“Artigo 1. ${ }^{\circ}$ Incumbe ao Poder Executivo, através do Departamento de Imprensa Nacional do Ministério da Justiça, a publicação:

I - das leis e dos demais atos resultantes do processo legislativo previsto na Constituição;

II - dos tratados, convenções e outros atos internacionais aprovados pelo Congresso Nacional;

(...)

Artigo 2. ${ }^{\circ}$. O Departamento de Imprensa Nacional do Ministério da Justiça exerce as suas funções de publicar atos e documentos oficiais por meio dos seguintes órgãos:

I-Diário Oficial;

II - Diário da Justiça;

(...)

Artigo 3. . . São obrigatoriamente publicados, na íntegra, no Diário Oficial:

I - as leis e os demais atos resultantes do processo legislativo previsto na Constituição;

II - os tratados, convenções e outros atos internacionais aprovados pelo Congresso Nacional e os respectivos decretos de promulgação; (...)”.

Sempre se entendeu que o tratado é obrigatório em virtude da ratificação; executório, em face da promulgação; e aplicável, em conseqüência da publicação. Mas, esclareça-se que todas essas providências não têm o condão de transformar o direito internacional em direito interno. Um tratado devidamente promulgado e publicado continua sendo norma de direito internacional. É dizer, as normas contidas no tratado promulgado continuam sendo normas de direito das gentes e não de direito interno, sendo desnecessária uma segunda intermediação legislativa dispondo, numa outra norma, sobre a matéria constante do tratado. Os tratados - explica FRANCISCO REZEK - "vigem internamente com sua roupagem original de tratados, e nessa qualidade, e sob esse exato título, revogam direito anterior de produção interna, tal como faria uma lei ordinária superveniente". ${ }^{81}$

A participação do Congresso no processo de conclusão de tratados internacionais, enfim, é uma só: aquela que aprova ou não o seu conteúdo, e mais nenhuma outra. Após ratificado e promulgado pelo Presidente da República, o tratado internacional continua sendo norma de direito internacional aplicável internamente. Não passa, com a promulgação, a ser norma de direito interno. Daí porque as nossas Constituições sempre se referiram à aplicação do tratado pelos tribunais. ${ }^{82}$

Assim é que o art. 102, III, $b$, da Carta Magna de 1988, como já foi visto, diz competir ao Supremo Tribunal Federal, julgar, mediante recurso extraordinário, as causas decididas em única ou última instância, quando a decisão recorrida "declarar a inconstitucionalidade de tratado ou lei federal", da mesma forma o fazendo com o Superior Tribunal de Justiça, quando lhe atribui a competência para 
julgar, mediante recurso especial, as causas decididas, em única ou última instância, pelos Tribunais Regionais Federais ou pelos Tribunais dos Estados, quando a decisão recorrida "contrariar tratado ou lei federal, ou negar-lhes vigência" (art. 105, III, a). Tratam-se de normas que consagram a plena vigência dos tratados, independentemente de lei especial. Como bem disse o então Ministro do STF, Oswaldo Trigueiro, ainda sob a égide da Carta Constitucional anterior, "se essa vigência dependesse de lei, a referência a tratado, no dispositivo constitucional, seria de todo ociosa. Por outras palavras, a Constituição prevê a negativa de vigência da lei e a negativa de vigência do tratado, exigido, para a validade deste a aprovação pelo Congresso, porém não sua reprodução formal em texto da legislação interna". ${ }^{83}$

O decreto executivo, assinado pelo Presidente da República, é ainda referendado pelo Ministro das Relações Exteriores, e acompanhado de cópia do texto do ato. A partir de então, tem o tratado plena vigência na ordem interna, devendo, por isso, ser obedecido tanto pelos particulares, como pelos juízes e tribunais nacionais.

Junho de 2001

\section{Notas}

1 Cf., ambos do Prof. Cachapuz de Medeiros, O poder legislativo e os tratados internacionais, Porto Alegre: L\&PM Editores/Instituto dos Advogados do Rio Grande do Sul, 1983; e O poder de celebrar tratados: competência dos poderes constituidos para a celebração de tratados, à luz do direito internacional, do direito comparado e do direito constitucional brasileiro, Porto Alegre: Sergio Antonio Fabris Editor, 1995.

2 Cf. Estevão Rezende Martins. A apreciação de tratados e acordos internacionais pelo Congresso Nacional, in Cançado Trindade, Antônio Augusto (Editor), A incorporação das normas internacionais de proteção dos direitos humanos no direito brasileiro, 2. ${ }^{a}$ ed. San José, Costa Rica/Brasília: Instituto Interamericano de Derechos Humanos (et all.), 1996, p. 263.

3 Cf. Valerio de Oliveira Mazzuoli. Tratados internacionais: com comentários à Convenção de Viena de 1969. São Paulo: Editora Juarez de Oliveira, 2001, pp. 158 e ss.

4 Cf. Haroldo Valladẽo, Aprovação de Ajustes Internacionais pelo Congresso Nacional, in Boletim da Sociedade Brasileira de Direito Internacional, jan./dez. 1950, p. 95 e ss.; VICENTE Marotta Rangel, A Constituição brasileira e o problema da conclusão dos tratados internacionais, in Problemas Brasileiros, n. $^{\circ}$ 31, São Paulo: Conselho Regional do Serviço Social do Comércio, out. 1965, p. 11 e ss.; Afonso Arinos de Melo Franco, Poder legislativo e político internacional, in Estudos de direito constitucional, Rio: Forense, 1957, p. 257 e ss.; PONTES DE

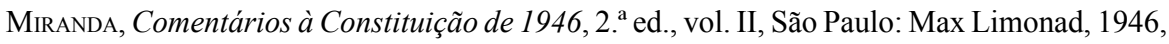
p. 404; Themístocles Brandão CaVAlcanti, A Constituição federal comentada, vol. II, Rio: José Konfino, 1952, p. 127 e ss.; e, CArlos Maximiliano, Comentários à Constituição brasileira, 5. a’ ed., rio: Freitas Bastos, 1954, p. 242 e ss.

5 Cf. Antônio Paulo Cachapuz de Medeiros. O Poder Legislativo e os tratados internacionais, cit., p. 76; e João Grandino Rodas. Tratados internacionais. São Paulo: Editora Revista dos Tribunais, 1991, p. 29. 
6 Hildebrando AcCioly. A ratificação e a promulgação dos tratados em face da Constituição Federal brasileira, in Boletim da Sociedade Brasileira de Direito Internacional. Rio de Janeiro, n. ${ }^{\circ}$ 7, jan./jun. 1948, pp. 5-11.

7 Hildebrando Accioly. Ainda o problema da ratificação dos tratados, em face da Constituição Federal Brasileira, in Boletim da Sociedade Brasileira de Direito Internacional. Rio de Janeiro, n. ${ }^{\text {1 }}$ 11/12, jan./dez. 1950, pp. 95-108,

Antônio Paulo Cachapuz de Medeiros. O poder de celebrar tratados: competência dos poderes constituídos para a celebração de tratados, à luz do direito internacional, do direito comparado e do direito constitucional brasileiro. Porto Alegre: Sergio Antonio Fabris Editor, 1995, p. 199. Haroldo Valladẽo. Aprovação de ajustes internacionais pelo Congresso Nacional, in Boletim da Sociedade Brasileira de Direito Internacional, Rio de Janeiro, n. ${ }^{\circ} 11-12$, jan./dez. 1950, pp. 95-108.

Hildebrando Accioly. Ainda o problema da ratificação dos tratados, em face da Constituição Federal Brasileira, cit., pp. 20-23.

11 Cf. João Grandino Rodas, Tratados internacionais, cit., p. 33.

12 João Grandino Rodas. Idem, p. 34.

13 Vide, por tudo, João Grandino Rodas, Idem, p. 33-37; cf., ainda, Antônio Paulo Cachapuz de MedeIros, O Poder de celebrar tratados, cit., p. 296 e ss.

14 Cf. Haroldo Valladão. Necessidade de aprovação pelo Congresso Nacional de acordo internacional, in Boletim da Sociedade Brasileira de Direito Internacional. Rio de Janeiro, n. ${ }^{\circ}$ 49/50, jan./dez. 1969 , p. 111.

15 Vide, por tudo, João Grandino Rodas, Op. cit., pp. 39-40.

16 A. P. Cachapuz de Medeiros. O Poder Legislativo e os tratados internacionais, cit., p. 144.

17 JoÃo Grandino Rodas. Op. cit., pp. 44-47.

18 Paolo Barile, Enzo Cheli e Stefano Grassi. Istituzioni di diritto pubblico, 8. ${ }^{\mathrm{a}}$ ed. Padova: CEDAM-Casa Editrice Dott. Antonio Milani, 1998, pp. 330-331.

Cf. Paolo Barile, Enzo Cheli e Stefano Grassi. Idem, p. 332.

20 JoÃo Grandino Rodas. Op. cit., p. 43.

21 Elcias Ferreira da Costa. Comentários breves à Constituição Federal. Porto Alegre: Sergio Antonio Fabris Editor, 1989, p. 115.

22 Cf. Pontes de Miranda. Comentários à Constituição de 1967 com a Emenda $n .^{\circ} 1$ de 1969, Tomo III, 3. a ed. Rio: Forense, 1987, p. 327.

23 José Francisco Rezek. Direito internacional público: curso elementar, 6. ${ }^{a}$ ed. São Paulo: Saraiva, 1996, p. 68.

24 Cf. José Francisco Rezek. Direito dos tratados. Rio: Forense, 1984, p. 333.

Nelson de Sousa Sampaio. O processo legislativo. São Paulo: Saraiva, 1968, pp. 54-55.

Valerio de Oliveira Mazzuoli. Direitos humanos \& relações internacionais. Campinas: Agá Juris, 2000, p. 73.

Cf. José Francisco Rezek. Direito dos tratados, cit., p. 334.

Cf. Valerio de Oliveira Mazzuoli. Direitos humanos \& relações internacionais, cit., p. 74.

Cf. José Francisco Rezek. Direito dos tratados, cit., p. 335.

MirTô Fraga. O conflito entre tratado internacional e norma de direito interno: estudo analítico da situação do tratado na ordem jurídica brasileira. Rio: Forense, 1998, p. 56.

32 Mirtô Fraga. Idem, p. 57.

33 Cf. Pedro Calmon, Curso de direito constitucional brasileiro, 4. ${ }^{\text {a }}$ ed. Rio: Freitas Bastos Editora, 1956, p. 156; e, Hildebrando Accioly, Tratado de direito internacional público, Tomo II, cit., p. 411. Nesse mesmo sentido: Funck-Brentano et Sorel. Précis du Droit des Gens. Paris, 1877, p. 106. 
Pontes de Miranda. Comentários à Constituição de 1967 com a Emenda $n .^{\circ} 1$ de 1969, Tomo III, cit., p. 330.

Pontes de Miranda. Op. cit., p. 336.

Estevão Rezende Martins. “A apreciação de tratados...”, cit., p. 264.

Pontes de Miranda. Op. cit., p. 334.

Cf. Luiz Flávio Gomes. A questão da obrigatoriedade dos tratados e convenções no Brasil: particular enfoque da Convenção Americana sobre Direitos Humanos, Revista dos Tribunais $\mathrm{n}{ }^{\circ}$ 710, p. 28.

Cf. Themistocles Brandão Cavalcanti. A Constituição Federal comentada, Vol. II, 3. ${ }^{\text {a }}$ ed. Rio: José Konfino Editor, 1956, p. 120.

José Francisco Rezek. Direito internacional público..., cit., p. 69.

Cf. Pontes de Miranda. Op. cit., p. 105.

José Francisco Rezek. Direito internacional público..., cit., p. 69.

Mirtô Fraga. Op. cit., p. 68-69.

Pontes de Miranda. Op. cit., p. 108.

Louis Henkin. Constitucionalism, democracy and foreign affairs. New York: Columbia University Press, 1990, p. 59.

Cf. nesse sentido, mas sem razão, Themistocles Brandão Cavalcanti, Op. cit., p. 120; Manoel Gonçalves Ferreira Filho, Comentários à Constituição brasileira de 1988, vol. I, 2. ${ }^{\text {a }}$ ed., São Paulo: Saraiva, 1997, p. 296; Amauri Mascaro NAScimento, Iniciação ao direito do trabalho, 23. ${ }^{a}$ ed., São Paulo: Editora LTr, 1997, p. 131; Alexandre de Moraes, Direitos humanos fundamentais, 3. ${ }^{\text {a }}$ ed., São Paulo: Atlas, 2000, p. 304; e CARLos WeIs, Direitos humanos contemporâneos, São Paulo: Malheiros Editores, 1999, p. 26.

Vide, por tudo, Valerio de Oliveira Mazzuoli. Direitos humanos \& relações internacionais, cit., pp. 76-77.

Cf. Mirtô Fraga. Op. cit., pp. 56-57.

Cf. Antônio Paulo Cachapuz de Medeiros. O Poder de celebrar tratados, cit., p. 118.

A. P. Cachapuz de Medeiros. Idem, p. 117.

Cf. Mirtô Fraga. Op. cit., p. 57.

Hildebrando Accioly. Parecer do Consultor Jurídico do Itamaraty, in Boletim da Sociedade Brasileira de Direito Internacional (8), 1948, pp. 164-166.

Antônio Paulo Cachapuz de Medeiros. O Poder Legislativo e os tratados internacionais, cit., p. 133-134; e também em $O$ poder de celebrar tratados, cit., pp. 468-470.

A. P. Cachapuz de Medeiros. Idem, ibidem.

Luiz Flávio Gomes. A questão da obrigatoriedade dos tratados..., cit., RT 710/28.

Cf. José Francisco Rezek. Direito dos Tratados, cit., p. 384.

A esse respeito, vide Valerio de Oliveira Mazzuoli, Direitos humanos \& relações internacionais, cit., pp. 109 e ss.

A. P. Cachapuz de Medeiros, O Poder de celebrar tratados, cit., p. 397.

Revista de Jurisprudência do TJRS, vol. 4, p. 193.

Cf. Valerio de Oliveira Mazzuoli. Direitos humanos \& relações internacionais, cit., pp. 109 e ss.

Cf. Estevão Rezende Martins, A apreciação de tratados..., cit., p. 264; e ainda, J. F. RezeK, Direito internacional público..., cit., p. 69.

José Francisco ReZeK. Idem, ibidem.

Vide, por tudo, Estevão Rezende Martins, A apreciação de tratados..., cit., pp. 264-271.

Valerio de Oliveira Mazzuoli. Direitos humanos \& relações internacionais, cit., p. 80.

Estevĩo Rezende Martins. Op. cit., p. 269.

Flávia Piovesan. Temas de direitos humanos. São Paulo: Max Limonad, 1998, p. 71.

Pontes de Miranda. Comentários..., cit., p. 114. 
68 Jõ̃o Grandino Rodas. Tratados internacionais, cit., pp. 53-54.

69 Mirtô Fraga. O conflito entre tratado internacional..., cit., p. 47.

70 Cf. Hildebrando Accioly \& G. E. do Nascimento e Silva. Manual de direito internacional público, 13. ${ }^{a}$ ed. São Paulo: Saraiva, 1998, p. 31.

71 José Francisco Rezek. Direito dos tratados, cit., p. 385.

72 Cf. José Francisco Rezek. Idem, pp. 385 e 387.

73 Cf. Valerio de Oliveira Mazzuoli. Direitos humanos \& relações internacionais, cit., p. 155.

74 Cf. Hans Kelsen. Teoria geral do direito e do Estado. Trad. Luís Carlos Borges. São Paulo: Martins Fontes, 1990, p. 367.

75 Cf. José Francisco Rezek. Direito dos tratados, cit., pp. 385-386.

76 Cf. Mirtô Fraga. Op. cit., p. 63.

77 Mirtô Fraga. Idem, pp. 63-64.

78 Cf. Vicente Marotta Rangel. Integração das convenções de Genebra no direito brasileiro, in Revista do Instituto de Pesquisas e Estudos Jurídico-Econômico-Sociais, Ano II, n. ${ }^{\circ}$ 3, Bauru: Instituição Toledo de Ensino, jan./mar. 1967, p. 202 (nota).

79 Mirtô Fraga. Op. cit., pp. 63-64.

80 Cf. José Francisco Rezek, Direito dos tratados, cit., p. 386.

81 José Francisco Rezek. Idem, p. 383.

82 Cf. Mirtô Fraga. Op. cit., pp. 64-65.

83 Trecho do voto proferido no $R E$ n. ${ }^{\circ}$ 72.154-PR, Tribunal Pleno, julg. 04.08.1971, in RTJ vols. 58 e 70, p. $71-72$.

\section{Resumo}

O presente trabalho teve por objetivo estudar o modo pelo qual a Constituição brasileira de 1988 disciplina a competência dos poderes constituídos para a celebração de tratados. Buscou-se analisar, dessa forma, o relacionamento dos poderes Legislativo e Executivo no que tange ao procedimento de celebração de tratados internacionais.

\section{Abstract}

The present work aimed at studying the model in which the 1988 Brazilian Constitution deals with the competence of constituted powers for the celebration of treaties. It was analyzed, this way, the Legislative and Executive relationship powers as to the proceedings for the celebration of international treaties.

Palavras-chave: Constituição brasileira. Tratados Internacionais. Direito Internacional Público.

Key-words: Brazilian Constitution. Internationals Treaties. International Public Law. 